\title{
PERMAINAN TRADISIONAL BETAWI UNTUK MENINGKATKAN KEMAMPUAN KOGNITIF SISWA DI TK MUTIARA
}

\author{
Ahmad Syaikhu, Ahmad Durul Napis \\ Sekolah Tinggi Keguruan dan Ilmu Pendidikan Kusuma Negara, Indonesia \\ corresponding e-mail: ahmadsyaikhu@stkipkusumanegara.ac.id
}

\begin{abstract}
This research aims to obtain data on improving cognitive abilities through Betawi's traditional game activities through song. The study was conducted at TK Mutiara Duri Kosambi Cengkareng, West Jakarta and the subject of this research is TK Mutiara B Group children. This study used a class action research method which was carried out with two cycles. Data is obtained from observation instruments, documentary studies and field notes. Observation of pre-cycle measures obtained an average of $53.95 \%$. In cycle 1 the average results of observations $71,042 \%$. Then in the second cycle cognitive ability has increased $18.53 \%$, with an average yield of $89.58 \%$. The results of research conducted at TK Mutiara show that Betawi traditional game activities through song can improve cognitive development of young children. The implications of this study suggest that teachers should implement learning by maximizing play activities. The teacher is also encouraged to be more careful in planning and implementing learning so as to achieve the goals set.
\end{abstract}

Keywords : Betawi's Traditional Game, Cognitive Ability, Early Childhood

\begin{abstract}
Abstrak
Penelitian ini bertujuan untuk memperoleh data tentang peningkatan kemampuan kognitif melalui kegiatan permainan tradisional Betawi dengan nyanyian. Penelitian dilaksanakan di TK Mutiara Duri Kosambi Cengkareng Jakarta Barat dengan subjek peneliti adalah anak TK Mutiara Kelompok B. Penelitian ini menggunakan metode penelitian tindakan kelas yang dilaksanakan dengan dua kali siklus. Data diperoleh melalui instrumen observasi, studi dokumenter dan catatan lapangan. Observasi tindakan pra siklus memperoleh rata-rata sebesar 53,95\%. Pada siklus 1 hasil observasi rata-rata sebesar $71,042 \%$. Kemudian pada siklus II kemampuan kognitif mengalami peningkatan mencapai 18,53\% dengan hasil ratarata $89,58 \%$. Hasil penelitian yang dilaksanakan di TK Mutiara menunjukan bahwa kegiatan permainan tradisional betawi dengan nyanyian dapat meningkatkan perkembangan kognitif anak usia dini. Implikasi penelitian ini menyarankan guru hendaknya melaksanakan pembelajaran dengan memaksimalkan kegiatan bermain. Pada guru juga dianjurkan untuk lebih teliti dalam merencanakan dan melaksanakan pembelajaran sehingga mencapai tujuan yang ditetapkan.
\end{abstract}

Kata Kunci: Permainan Tradisonal Betawi, Kemampuan Kognitif, Anak Usia Dini 


\section{Pendahuluan}

Pendidikan dan pembelajaran bagi anak sangat penting, karena anak berada pada rentang usia yang disebut dengan masa keemasan yaitu masa anak tumbuh dan berkembang dengan cepat dan sangat menentukan bagi pertumbuhan dan perkembangan selanjutnya dalam periode-periode kehidupan manusia (Ige, 2011; Kim, 2011; De Haan, Elbers, \& Leseman, 2014). Pendidikan Anak Usia Dini (PAUD) bertujuan untuk mempersiapkan masa depan anak menjadi pribadi yang utuh ataupun sebagai bagian dari anggota sosial masyarakat. Taman Kanak-Kanak (TK) adalah sebagai salah satu lembaga pendidikan yang bertugas melakukan usaha dan upaya pembinaan melalui rangsangan pendidikan dalam bentuk pembelajaran, diharapkan melalui pembelajaran yang diberikan, maka anak akan memiliki kesiapan untuk memasuki jenjang pendidikan lebih lanjut.

Dalam hal itu, anak-anak merupakan calon generasi yang unggul tidak dapat tumbuh dengan tanpa bantuan orang di sekitarnya (Duncan \& Sojourner, 2013; Fleer, 2009). Anak-anak memerlukan lingkungan yang baik dan positif agar dapat memberikan stimulasi terhadap aspek-aspek perkembangan dalam dirinya (Elmanora, Dwi Hastuti, 2015). Anak-anak memerlukan pengalaman yang positif, pengalaman yang memiliki kesan yang baik sehingga berdampak positif pada masa berikutnya dalam kehidupannya (McFarland-Piazza \& Saunders, 2012; Shin \& Lee, 2011). Hal ini menjadi penting untuk mewujudkan masa depan anak yang baik dan kehidupan yang lebih bermakna.

Anak-anak berpikir melalui dunianya sendiri, berfikir dengan kacamata pribadi tentang alam sekitar dan kehidupan yang dialaminya (Devi, Fleer, \& Li, 2018). Proses berpikir tersebut membentuk pola pikir yang kemudian tumbuh dan mengembangkan daya pikir, daya cipta serta daya karsa yang merupakan tolak ukur perkembangan kognitif (Papandreou, 2014). Anak tidak bisa dipaksa dengan pemikiran orang dewasa, namun anak dapat belajar dari orang dewasa dengan mengamati, berinteraksi dan imitasi (Moss, 2012).

Dalam hal itu, anak akan membangun pengetahuannya sendiri melalui pemahaman-pemahaman yang didapat atas kegiatan-kegiatan yang dilakukan dalam permainan maupun kegiatan sosial bersama teman sebaya dan juga orang dewasa serta keluarga yang kerap berinteraksi dengannya (Chien, Hsiung, Chen, \& Lin, 2010; Mashford-Scott, Church, \& Tayler, 2012). Pemikiran anak tentang sesuatu tentu akan jauh berbeda dengan konsep orang dewasa, anak akan memiliki arti sendiri atas sesuatu maupun aktivitas yang dilakukan dengan mengamati, melakukan observasi dan juga penelusuran tentang hal-hal yang belum diketahui maupun hal-hal yang hendak diketahui (Ergazaki \& Zogza, 2013).

Oleh karena itu, pembelajaran harus terus diciptakan dengan membangun pengalaman-pengalaman yang menyenangkan untuk anak. Pembelajaran menjadi suatu proses berkelanjutan yang mengandung unsur-unsur pendidikan, pengajaran, 
pelatihan, bimbingan dan kepemimpinan dengan tumpuan khas kepada usaha transfer pengetahuan dan berbagai wawasan, nilai-nilai moral agama dan budaya, yang memberikan manfaat secara nyata dalam menjalankan kehidupan sehari-hari serta mempersiapkan diri menjadi manusia yang bertanggung jawab atas pribadi dan keluarga.

Dunia anak adalah dunia bermain, karena bermain merupakan kegiatan yang menyenangkan bagi anak. Bermain juga tuntutan dan kebutuhan bagi anak TK. Dengan bermain anak dapat memuaskan tuntutan dan kebutuhan perkembangan anak dalam dimensi motorik, kognitif, kreativitas, bahasa, emosi, sosial, nilai dan sikap hidup. Bermain dapat membawa harapan dan ambisi tentang dunia yang memberikan kebahagiaan dan memungkinkan anak berkhayal dengan imajinasi tentang sesuatu.

Dalam hal lain, sebagian besar masyarakat masih memiliki pandangan terkait TK merupakan miniatur sekolah Dasar (SD) yang memungkinkan anak belajar dengan serius. Sehingga, aspek bermain sebagai kebutuhan anak menjadi dikesampingkan apalagi dalam pengenalan permainan tradisional. Akibatnya permainan tradisional terpinggirkan dalam dunia pendidikan umumnya, dan pendidikan anak khususnya, ini terbukti dengan ketidaktahuan anak dengan namanama permainan tradisional. Banyaknya bermunculan permainan-permainan modern yang bermunculan, sehingga permainan tradisional tidak lagi dimanfaatkan sebagai salah satu kegiatan yang bisa dilakukan atau diajarkan di sekolah. Sehingga secara tidak sadar menyebabkan hilangnya salah satu elemen kebudayaan anak, padahal salah satu peran pendidikan adalah mewariskan budaya sekaligus membawa perubahan (Adiwikarta, 2017).

Dalam permainan tradisional ada permainan yang melibatkan penggunaan gerak tubuh atau anggota badan dan ada permainan yang menggunakan atau melibatkan nyanyian. Permainan tradisional yang menggunakan nyanyian utamanya mengandung ajakan untuk menanamkan nilai-nilai kebaikan, etika dan moral yang harus dimiliki anak. Disamping itu dengan permainan tradisional mampu mengembangkan imajinasi, daya kreatif, kemampuan berpikir, kecerdasan emosional serta spiritual anak akan berkembang. Oleh karena itu kajian tentang pentingnya permainan tradisional dalam pembelajaran anak usia dini telah menjadi perhatian dunia internasional.

Bermain tidak bisa dipisahkan dari dunia anak dan menjadi bagian yang penting dalam pertumbuhan dan perkembangan anak, melalui bermain anak akan dapat mengembangkan seluruh aspek kemampuan dan kecerdasannya, karena bermain dilakukan dengan penuh kesenangan dan sukarela tanpa melihat hasil akhir dan tanpa paksaan dan tekanan dari siapapun (Musfiroh, 2005) Bermain adalah kegiatan yang dilakukan menggunakan alat ataupun tanpa alat dengan menghadirkan kesenangan serta mengembangkan imajinasi pada anak (Sudono, 
2000). Bermain merupakan kegiatan yang dilakukan untuk menimbulkan kesenangan dan kebahagiaan, tidak melihat hasil akhir. Melalui bermain anak dapat belajar banyak hal, tanpa disadari dan tanpa merasa terbebani (Semiawan, 2008)

Berdasarkan pendapat diatas, disimpulkan bahwa kegiatan bermain merupakan suatu kegiatan yang dilakukan secara berulang-ulang dapat menimbulkan kesenangan dan kepuasan bagi seseorang. Bermain juga memberikan kesempatan kepada anak untuk bereksplorasi, menemukan hal-hal baru, mengekspresikan perasaan, berkreasi, berjalan menyenangkan dan menstimulasi seluruh aspek perkembangannya.

Pada dasarnya, bermain memiliki tujuan utama yaitu memelihara pertumbuhan dan perkembangan anak secara optimal melalui cara dan pendekatan yang menyenangkan, kreatif, interaktif dan terintegrasi dengan lingkungan bermainnya. Melalui bermain diharapkan anak mampu mengendalikan dirinya sendiri, memahami kehidupan dan kebutuhannya, serta mampu mengembangkan seluruh dimensi perkembangan dan pertumbuhannya baik kognitif, motorik, kreativitas, bahasa, emosi, sosial, nilai dan sikap hidup (Musfiroh, 2005).

Kegiatan bermain juga merupakan kegiatan yang menyenangkan, sehingga bermain menjadi sarana belajar yang efektif bagi anak. Melalui bermain pertumbuhan otot dan otak anak akan terus terstimulasi. Selain itu, dengan bermain anak dapat mengekspresikan dirinya dan melakukan eksplorasi terhadap hal-hal baru di sekelilingnya dan memantapkan berbagai hal yang telah diketahui anak sebelumnya. Perkembangan potensi diri yang dimiliki anak akan terbantu perkembangan dan pertumbuhannya secara optimal baik fisik, mental, intelektual, moral dan spiritual (Huda, Faeruz, \& Hayati, 2019)

Permainan memerlukan media untuk dapat membantu kelancaran dalam menjalankan kegiatan. Media sebagai segala bentuk dan sarana yang digunakan untuk menyampaikan pesan pembelajaran dan informasi (Sadiman, n.d.) Media menembus budaya dan membanjiri masyarakat dengan informasi dengan sangat cepat (Christ \& Potter, 1998) Penggunaan media dalam pembelajaran perlu memberikan pengenalan dan persiapan (Catron \& Allen, 2008) Dalam pendidikan anak usia dini, media pembelajaran yang digunakan sedikit berbeda dengan media pembelajaran yang digunakan pada jenjang pendidikan yang lebih tinggi (Rolina, n.d.) Anak-anak menjelajahi dunia mereka melalui upaya meniru, bermain dengan 'teknologi' yang mungkin digital atau tidak (Alper \& Herr-Stephenson, 2013)

Permainan terbagi menjadi beberapa jenis; (1). Permainan eksploratif, (2) Permainan sosial, (3) Permainan imajinatif, (4) Permainan dinamis, (5) Permainan dengan keterampilan, dan (6) Permainan teka-teki (Tedjasaputra, 2001) Permainan tersebut dapat dikembangkan dalam kegiatan pembelajaran di dalam kelas maupun di luar kelas dengan memperhatikan prinsip-prinsip yang relevan sesuai dengan kebutuhan anak. 
Permainan tradisional, sebagai salah satu jenis permainan yang merupakan sesuatu yang diwariskan secara turun-temurun dari satu generasi ke generasi berikutnya yang terdapat dalam masyarakat yang merupakan hasil dari penggalian budaya lokal, terkandung di dalamnya nilai-nilai pendidikan, nilai budidaya, serta dapat menyenangkan hati yang memainkannya (Wahyuningsih, 2011) Menurut Bishop dan Curtis, sebagaimana yang dikemukakan oleh Meha bahwa permainan tradisional diturunkan dari satu generasi ke generasi berikutnya, di dalamnya terkandung nilai-nilai positif yang bernilai (Meha, 2011) Permainan tradisional pada dasarnya mengandung unsur peraturan yang harus diikuti yang memainkannya serta melibatkan lebih dari satu orang.

Seperti permainan lainnya, permainan tradisional juga memiliki fungsi psikologis bagi perkembangan anak. Pada semua tahapan usia anak, permainan atau bermain menjadi kegiatan yang memberikan rasa senang dan perasaan yang positif. Permainan tradisional bagi anak sangat relevan dengan tujuan pendidikan, tidak hanya sebagai upaya pelestarian budaya daerah, tetapi juga akan membentuk kepribadian dan sikap anak. Dalam prakteknya jenis permainan tradisional sangat banyak dan variatif.

Karakteristik permainan tradisional dapat dicermati sebagai berikut, pertama, permainan tradisional berusaha menggunakan dan memanfaatkan alam sebagai sumber bermaian yang menjadi bahan permainan. Maka daya kreatif dan spirit perlu untuk memberdayakan alam sekitar menjadi lebih tepat guna untuk digunakan sebagai permainan pembelajaran. Misalkan egrang yang dibuat dari kayu, mobilmobilan dari kulit jeruk, pistol-pistolan atau tembak tembakan dari pelepah pisang atau dari batang tanaman singkong dan lain sebagainya.

Kedua, permainan dapat dilakukan oleh lebih dari satu orang. Dua orang, tiga orang atau bahkan lebih banyak lagi menjadi kelompok bahkan kelompokkelompok. Hal ini menjadi ciri khas yang merupakan kelebihan permainan tradisional yang menjadikan anak lebih mudah dan sering untuk melakukan interaksi sosial dengan temannya, bekerja sama, melatih kekompakkan, bertanggung jawab pada diri sendiri dan orang lain, bersikap adil, jujur serta membangun empati dan simpati. Hal ini yang kini luput dalam permainan modern, membangun kebersamaan dalam kegiatan, sebagai contoh permainan Cici Putri, Gobak Sodor, serta Tarik tambang.

Ketiga, dalam permainan tradisional terdapat nilai-nilai luhur dan pesan-pesan moral tertentu, seperti nilai-nilai kejujuran, tanggung jawab, kerja sama, kerja keras, kepedulian terhadap teman, kemandirian dalam menyelesaikan masalah, gotong royong, saling membantu dengan anggota bermaian, melatih kesabaran terhadap teman dan lawan, serta membangun jiwa kompetisi untuk berlomba-lomba dalam kebaikan, saling menghargai, memiliki keakraban, mempunyai solidaritas yang 
tinggi, dan kemampuan untuk menaati peraturan yang berlaku dalam permainan yang memungkinkan menerima kemenangan atau kekalahan.

Keempat, fleksibilitas permainan tradisional. Konsep permainan tradisional dapat dilakukan di dalam ruang (indoor) ataupun di luar ruangan (out door), hal ini sesuai dengan konteks permainan yang hendak dilakukan dengan memperhatikan kebutuhan, keamanan serta kenyamanan dalam permainan.

Kelima, Pengalaman permainan dibangun atas interaksi sosial maupun emosional antara masing-masing anak dalam permainan. Hal ini, menjadikan anak pribadi yang tangguh dan memiliki jiwa kolektivitas, empati maupun simpati.

Permainan anak Betawi pada kekayaan budaya tradisi yang dimiliki, khususnya dalam permainan yang menggunakan nyanyian telah mengalami tumbuh kembang seiring perkembangan jaman. Permainan anak Betawi terutama yang menggunakan nyanyian dari waktu ke waktu mengalami perubahan (Tarwiyah, 2010)

Permainan tradisional Betawi dengan unsur yang melibatkan nyanyian dekat dengan nilai-nilai filosofi dan kebudayaan yang dapat dijadikan sebagai sarana untuk mengembangkan dan menumbuhkan kecerdasan anak. Permainan yang menggunakan nyanyian juga dapat memberikan kontribusi dalam penerapan pendidikan multikultural pada level PAUD, sehingga anak akan dipersiapkan menghadapi dunia yang tanpa batas dengan menghargai perbedaan pandangan, tetapi juga tidak terlepas dari akar budaya tempat mereka dibesarkan dan hidup di dalamnya (Tarwiyah, 2010).

Permainan Betawi yang menggunakan nyanyian terdiri dari 13 permainan. Seperti Cici Putri, Ulabang, Wak-Wak Gung, Keripik Jengkol, Pung-Pung Balong, Tug Tugene, atau Nenek Gerondong, Sim-Sim Terima Kasim, unsur nyanyian Umpet Batu, Serundang Kacang Tanah, Orang Kaya Miskin, Deng-dengan, Baris TempeTempe dan Cah Gulali.

Sementara itu, kognitif merupakan proses berfikir yang meliputi kemampuan individu untuk menghubungkan, menilai dan mempertimbangkan suatu kejadian atau peristiwa. Proses kognitif berhubungan dengan tingkat kecerdasan yang menandai seseorang dengan berbagai minat yang ditunjukkan kepada ide-ide belajar (Susanto, 2016) sebuah proses yang terjadi secara internal dalam pusat susunan syaraf pada saat manusia berpikir. Kemampuan kognitif berkembang secara bertahap sejalan dengan perkembangan fisik dan syaraf-syaraf yang berada di pusat susunan saraf.

Tahap-tahap perkembangan intelektual individu serta perubahan umur sangat mempengaruhi kemampuan individu mengamati ilmu pengetahuan (King, 2010) Demikian pula lingkungan fisik anak, jadi dapat dikatakan bahwa struktur kognitif anak mengkonstruksi lingkungan fisik (Olson \& Hergenhahn, 2009) Dalam hal itu, bermain anak-anak terfasilitasi perkembangan bahasa, keterampilan 
komunikasi, perkembangan emosi, keterampilan sosial, keterampilan pengambilan keputusan, dan perkembangan kognitif (Yudrik, 2011)

Kognitif berhubungan dengan kecerdasan, lebih spesifik kognitif memiliki sifat pasif atau statis yang merupakan potensi, atau daya untuk memahami sesuatu. Sedangkan kecerdasan lebih bersifat aktif yang merupakan aktualisasi atau perwujudan dari daya atau potensi tersebut yang bersifat aktivitas atau perilaku (Ali \& Asrori, 2010)

Dalam konsep umum menurut Drever, kognitif adalah istilah umum yang mencakup segenap metode pemahaman, yakni persepsi, imajinasi, penangkapan makna, penilaian dan penalaran Oleh karena itu, secara sederhana kemampuan kognitif dapat dipahami sebagai kemampuan anak untuk berpikir lebih kompleks serta kemampuan melakukan penalaran dan pemecahan masalah.

Berdasarkan pendapat beberapa ahli dapat disimpulkan bahwa kemampuan kognitif anak adalah proses psikologis yang meliputi kegiatan memperoleh, menyusun dan menggunakan pengetahuan seperti mengingat, berpikir, menimbang, mengamati, menganalisis, mengevaluasi dan memecahkan persoalan yang berlangsung melalui interaksi dengan lingkungan.

Ada beberapa aspek utama kemampuan kognitif menurut Thurstone, bahwa pengembangan kognitif merupakan perwujudan dari kemampuan primer yaitu : a).Kemampuan verbal, b).Kemampuan kelancaran kata-kata, c).Kemampuan mengenal angka, d).Kemampuan Keruangan, e).Kemampuan ingatan, f).Kemampuan persepsi, g).Kemampuan menalar (Cohen \& Stanczak, 2000)

\section{Model Permainan Tradisional Betawi dengan Nyanyian}

\section{Model Pertama, Cici Putri}

Permainan tradisional ini dimainkan oleh empat sampai enam anak. Permainan ini diawali dengan proses pemilihan pemimpin yang dimulai dengan kegiatan hompimpa atau gambreng, setiap pemain duduk melingkar sambil menyodorkan dua jari tangan kanan, jari telunjuk dan jari tengah. Jari-jari yang lain dikepalkan ke dalam. Pemain yang mendapatkan giliran diwajibkan menyilang satu tangannya ke pundak. Permainan diteruskan sampai setiap pemain/anak mendapatkan giliran sehingga semua pemain menyilangkan kedua tangannya ke pundak masing-masing. Untuk proses berikutnya pemimpin permainan akan bertanya satu persatu kepada peserta; (Tanya) ini pintu apa? (Jawab) pintu kayu. (Tanya) kuncinya kemana?. (jawab) kecebur (tenggelam). (Tanya) kecebur dimana ?, (jawab) di kali, (Tanya) bisa dibuka apa ngga, (jawab) bisa, Setelah dijawab maka pemimpin akan menarik tangan peserta secara mudah yang dihilangkan di depan dada ke pundaknya. Namun untuk tangan yang satunya berbeda. 
Model Kedua, Permainan Ular kelabang/Wak Wak Gung

Permainan ini terdiri dari enam orang anak, semakin banyak jumlah pemain akan semakin menyenangkan. Dimainkan oleh anak-laki-laki dan perempuan. Sebelum bermain anak-anak memilih dua orang sebagai penjaga gerbang. Kedua penjaga tersebut melakukan suit yang menang menjadi bintang yang kalah menjadi bulan. Kedua penjaga gerbang kemudian saling berpegangan tangan mereka diangkat ke atas membentuk seperti gerbang mereka bersiap-siap menangkap teman yang melewati gerbang, semua pemain yang lain berbaris memegang pundak di depan temannya.

Anak yang paling depan mulai berjalan sambal mengacak pinggang dan masuk gerbang sambal bernyanyi, saat anak-anak bernyanyi lagu ular kelabang gerbang ditutupkan satu anak tertangkap, anak yang tertangkap kemudian ditanya oleh penjaga gerbang mau bintang atau bulan, anak yang tertangkap kemudian menjawab jika memilih bintang anak tersebut berlari menjaga gerbang sebagai bintang. Jika memilih bulan anak tersebut berlari ke belakang sebagai bulan, permainan berlanjut anak-anak bernyanyi lagi hingga satu anak tertangkap, setelah semua tertangkap semua anak berbaris di belakang gerbang yang telah dipilihnya, kemudian masing-masing penjaga gerbang melakukan suit, jika salah satu penjaga gerbang menang suit maka anak-anak yang berbaris di belakang penjaga gerbang yang kalah pindah ke belakang penjaga gerbang yang menang suit, penjaga gerbang yang menang merentangkan tangan menjadi ular kelabang, penjaga yang kalah berlari-lari mencoba menangkap ekor ular kelabang tertangkap sekarang tinggal menangkap kepala ular kelabang. Jika sudah tertangkap semua maka permainan sudah selesai.

\section{Metode}

Penelitian ini melibatkan anak usia 5- 6 tahun melalui kegiatan permainan tradisional betawi dengan nyanyian dilaksanakan di TK Mutiara Duri Kosambi Cengkareng Jakarta Barat dengan subjek penelitian adalah anak TK Mutiara. Desain dalam penelitian ini diambil desain action research model Kemmis dan Mc.Taggart. Penelitian tindakan ini meliputi empat tahap yaitu (1) perencanaan (planning), (2) tindakan (action), (3) pengamatan (observation), dan (4) refleksi (reflection) (Taggart, Koskela, \& Rooke, 2014) Model penelitian tindakan spiral ini bertujuan untuk memperbaiki praktek-praktek pembelajaran dan meningkatkan mutu proses belajar mengajar.

Penelitian tindakan ini, dilaksanakan dalam dua siklus, dimana rancangan kegiatan untuk setiap siklusnya dijabarkan dalam Rencana Pelaksanaan Pembelajaran Harian (RPPH). Dua siklus yang dilakukan tersebut mengalami perubahan rencana perbaikan dengan hasil yang diharapkan sesuai dengan kebutuhan pembelajaran pada anak. 


\section{Hasil dan Pembahasan}

Setelah dilaksanakan tindakan, maka temuan hasil penelitian di lapangan setelah dibandingkan dengan sebelum tindakan sampai pada dilaksanakannya tindakan siklus II. Indikator keberhasilan tindakan dalam penelitian ini adalah terjadinya peningkatan kemampuan kognitif anak dalam aspek penguasaan kemampuan verbal, kelancaran kata-kata, mengingat kata dan angka, kemampuan menyelesaikan masalah dan penalaran mengalami peningkatan secara kualitatif dan kuantitatif. Kemampuan kognitif anak di TK tempat penelitian mengalami peningkatan dari pra-tindakan, siklus I dan siklus II, peningkatan tersebut ditandai dengan skor/nilai yang diperoleh samua anak pada akhir observasi siklus II, yakni semua responden telah tuntas pada tingkat kemampuan kognitifnya.

Hal ini dapat dilihat dari tindakan pra siklus memperoleh rata-rata sebesar $53,95 \%$ yang menunjukan bahwa anak memiliki perkembangan kognitif yang masih rendah sehingga dilaksanakan tindakan siklus 1 . Pada siklus 1 hasil observasi ratarata sebesar $71,042 \%$. Pada siklus 1 mengalami peningkatan mencapai $17,092 \%$. Dengan hasil tersebut maka perlu dilakukan tindakan pada siklus II perkembangan kognitif anak usia 5-6 tahun anak juga mengalami peningkatan mencapai 18,53\% dengan hasil rata-rata 89,58\%. Dengan demikian seluruh anak mengalami peningkatan dan mencapai target $80 \%$. Sehingga diperoleh hasil bahwa kegiatan yang dilaksanakan pada siklus II ini berhasil dengan baik sehingga diperoleh hasil meningkatkan perkembangan kognitif anak usia 5-6 tahun dapat dilakukan melalui kegiatan permainan tradisional Betawi dengan nyanyian.

Hasil pengamatan menunjukan bahwa anak merasa senang belajar sambil bermain melalui cara yang menarik perhatiannya. Hal ini memberikan motivasi kepada anak untuk aktif melakukan proses pembelajaran sampai selesai. Dengan suasana belajar yang melibatkan aspek visual, auditori, dan kinestetik serta kemampuan penalaran dan memecahkan masalah yang terdapat dalam permainan tradisional Betawi Cici Putri dan Ular Kelabang membuat anak tidak bosan dalam belajar. Penelitian ini diperkuat oleh Beaty bahwa dalam pencarian pengetahuan anak menginternalkan informasi yang diperoleh dari interaksi sensori dengan dunia sekitarnya (Beaty, 1994)

Permainan Cici Putri dan Ular Kelabang adalah kegiatan permainan yang mampu meningkatkan kemampuan verbal, kemampuan mengenal angka, kemampuan mengingat konsep bentuk, warna dan ukuran, kemampuan memecahkan masalah dan penalaran. Kemampuan-kemampuan tersebut menjadi sangat penting untuk dikembangkan sebab, hal tersebut merupakan ciri yang paling terlihat dalam dunia sekeliling anak dan dapat membantu anak menyelesaikan masalah dalam kehidupannya serta beradaptasi dengan lingkungannya (Ratnaningrum \& Arifah, 2016) 
Dalam pelaksanaan penelitian, dimulai dari tahapan perencanaan, tahap tindakan, tahap pengamatan dan tahap refleksi peneliti mendapatkan beberapa temuan yang berkaitan dengan yang penelitian ini, antara lain: (1). Kegiatan permainan tradisional yang menggunakan nyanyian merupakan kegiatan yang menyenangkan bagi anak untuk berekspresi. (2). Dalam kegiatan permainan tradisional ini sangat jarang dilakukan oleh anak di rumah maupun di sekolah, sehingga membuat anak anak tertarik untuk melakukannya lagi. (3). Kemampuan kognitif anak mengalami peningkatan dibandingkan saat sebelum diberikan kegiatan permainan tradisional yang menggunakan nyanyian. (4). Peneliti dan guru selalu memotivasi anak dalam melakukan kegiatan. (5). Dengan adanya motivasi secara terus menerus 13 anak masuk kategori tertinggi dan 2 anak lainnya masuk kategori sedang.

\section{Simpulan}

Pada saat bermain tradisional Betawi dengan nyanyian anak akan belajar mengungkapkan perasaan, hal ini ditunjukan dalam ekspresi dan kegembiraan anak. Selain itu dengan diajak bermain dalam proses belajar anak akan lebih cepat mengingat syair lagu yang sudah didengarnya, dan cepat menyukainya. Hal ini sangat membantu anak mengikuti proses kegiatan belajar mengajar dan membuat anak lebih mudah diterima oleh kelompok teman sebayanya.

Penggunaan kegiatan permainan tradisional Betawi dengan nyanyian telah memberikan kesempatan kepada anak untuk lebih mengenal dan mengetahui jenis permainan Betawi terutama permainan Betawi dengan nyanyian. Setelah mendapatkan tindakan perkembangan kognitif anak untuk mengingat dan menghafal syair-syair lagu, mengalami peningkatan setelah dilakukan tindakan hasil rata-rata kemampuan kognitif anak 89,58\%. Dengan demikian seluruh anak mengalami peningkatan dan mencapai target $80 \%$.

Langkah-langkah yang sesuai untuk tercapainya tujuan yang diharapkan yaitu menyiapkan segala sesuatu seperti membuat program pelaksanaan atau satuan kegiatan harian dengan metode praktek langsung melalui permainan tradisional, materi disesuaikan dengan tema, guru menyiapkan media peralatan-peralatan yang mendukung pada saat kegiatan permainan. Contoh menyiapkan lokasi untuk permainan di teras dan halaman serta alat yang digunakan misalnya batu kerikil untuk bermain umpat batu. Dalam hal ini langkah awal yang penting agar kegiatan dapat berjalan sesuai dengan rencana dan sebelum guru memulai permainan terlebih dahulu anak-anak menghafalkan syair lagu-lagu permainan betawi misalkan syair lagu cici putri, umpat batu, wak-wak gung, nenek grondong, orang miskin orang kaya.

Setelah anak-anak menghafal syair lagu-lagu kemudian guru memulai mengajak anak-anak untuk bermain. Sebelum bermain guru membuat aturan 
permainan sehingga dalam bermain dapat berjalan dengan lancar. Saat anak-anak bermain guru juga harus memperhatikan tingkah laku anak, hal ini dilakukan untuk mengetahui keaktifan anak dalam menghafalkan atau mengingat syair lagu, selain itu juga guru harus melakukan evaluasi dengan melakukan tanya jawab atau anak menceritakan kembali kegiatan yang dilakukan dengan bahasa sederhana.

Implikasi dari penelitian ini dapat diterapkan untuk meningkatkan perkembangan kognitif anak dengan baik dengan memberikan kegiatan permainan tradisional Betawi dengan nyanyian. Kegiatan bermain khususnya melalui permainan tradisional betawi dapat menarik minat anak untuk bermain juga memperkenalkan jenis-jenis permainan tradisional Betawi. Penelitian ini juga merupakan upaya pembelajaran bagi guru agar dapat menambah wawasan dan pengetahuan mengenai metode-metode pengembangan yang dapat meningkatkan kemampuan kognitif anak.

\section{Daftar Rujukan}

Adiwikarta, S. (2017). Sosiologi pendidikan: Analisis Sosiologi Tentang Praktis Pendidikan.

Ali, M., \& Asrori, M. (2010). Psikologi perkembangan peserta didik. Jakarta: PT. Busmi Aksara.

Alper, M., \& Herr-Stephenson, R. (2013). Transmedia play: Literacy across media. Journal of Media Literacy Education, 5(2), 2.

Beaty, J. J. (1994). Observing development of the young child. Merrill.

Catron, C. E., \& Allen, J. (2008). Early childhood curriculum: A creative play model. Prentice hall.

Chien, S., Hsiung, C., Chen, S., \& Lin, C. (2010). Fragrant Bamboo : The Constructivist Inquiry-based Science Project Curriculum Implementing Place-based Education for Preschool Children in, 4(2), 99-126.

Christ, W. G., \& Potter, W. J. (1998). Media literacy, media education, and the academy. Journal of Communication, 48(1), 5-15.

Cohen, M. J., \& Stanczak, D. E. (2000). On the reliability, validity, and cognitive structure of the Thurstone Word Fluency Test. Archives of Clinical Neuropsychology, 15(3), 267-279.

De Haan, A. K. E., Elbers, E., \& Leseman, P. P. M. (2014). Teacher-and child-managed academic activities in preschool and kindergarten and their influence on children's gains in emergent academic skills. Journal of Research in Childhood Education, 28(1), 43-58. http:/ / doi.org/10.1080/02568543.2013.851750

Devi, A., Fleer, M., \& Li, L. (2018). "We set up a small world": preschool teachers' involvement in children's imaginative play. International Journal of Early Years Education, 26(3), 295-311. http:// doi.org/10.1080/09669760.2018.1452720

Duncan, G. J. 1., \& Sojourner, A. J. 2. (2013). Can Intensive Early Childhood Intervention Programs Eliminate Income- Based Cognitive and Achievement Gaps? Journal of Human Resources, 48(4), 945-968. http://doi.org/10.1353/jhr.2013.0025 
Elmanora, Dwi Hastuti, I. M. (2015). Family Welfare and Home Environment Quality on Preschool Aged Children Abstract. Jur. Ilm. Kel E Kons., 8(2), 96-105.

Ergazaki, M., \& Zogza, V. (2013). How does the model of Inquiry-Based Science Education work in the kindergarten: The case of biology. Review of Science Mathematics \& ICT Education, 7(2), 73-97. Retrieved from http:/ / www.proxy.its.virginia.edu/login?url=http:/ / search.ebscohost.com/log in.aspx?direct $=$ true\&db=ehh\&AN=95029954\&site $=$ ehost-live\&scope $=$ site

Fleer, M. (2009). Supporting scientific conceptual consciousness or learning in "a Roundabout Way" in play-based contexts. International Journal of Science Education, 31(8), 1069-1089. http:// doi.org/10.1080/09500690801953161

Huda, H., Faeruz, R., \& Hayati, M. (2019). Permainan Kolase Untuk Meningkatkan Motorik Halus Pada Kelompok A Tk Muslimat NU Banjarmasin. Journal of Early Childhood Education (JECE), 1(2), 1-8.

Ige, A. M. (2011). The Challenges Facing Early Childhood Care, Development and Education (ECCDE) in an Era of Universal Basic Education in Nigeria. Early Childhood Education Journal, 39(2), 161-167. http://doi.org/10.1007/s10643-0110443-3

Kim, J. E. (2011). Holistic Development of the Young Child through an Integrated Curriculum : Rudolf Steiner's Anthroposophical Research, 5(1), 161-170.

King, L. A. (2010). Psikologi umum: Sebuah pandangan apresiatif. Jakarta: Salemba Humanika.

Mashford-Scott, A., Church, A., \& Tayler, C. (2012). Seeking Children's Perspectives on their Wellbeing in Early Childhood Settings. International Journal of Early Childhood, 44(3), 231-247. http:/ / doi.org/10.1007/s13158-012-0069-7

McFarland-Piazza, L., \& Saunders, R. (2012). Hands-on parent support in positive guidance: early childhood professionals as mentors. Australasian Journal of Early Childhood, 37(1), 65-73.

Moss, P. (2012). Caring and Learning Together: Exploring the relationship between parental leave and early childhood education and care. European Journal of Education, 47(4), 482-493. http:// doi.org/10.1111/ejed.12003

Musfiroh, T. (2005). Bermain sambil belajar dan mengasah kecerdasan. Jakarta: Depdiknas.

Olson, M. H., \& Hergenhahn, B. R. (2009). Theories of Learning. Jakarta: Kencana.

Papandreou, M. (2014). Communicating and thinking through drawing activity in early childhood. Journal of Research in Childhood Education, 28(1), 85-100. http:/ / doi.org/10.1080/02568543.2013.851131

Ratnaningrum, C. D., \& Arifah, S. (2016). Gambaran dampak permainan game elektronik pada anak usia sekolah di wilayah Kelurahan Manisrejo Kabupaten Magetan. Universitas Muhammadiyah Surakarta.

Rolina, N. (n.d.). Muhyidin.(2014). Ensikopledia Pendidikan Anak Usia Dini, Metode $\mathcal{E}$ Media Pembelajaran. Yogyakarta: Insan Madani.

Sadiman, A. S. (n.d.). R, Raharjo, dkk. 2012. Media Pendidikan (Pengertian, Pengembangan, Dan Pemanfaatanya). Jakarta: PT RajaGrafindo Persada.

Semiawan, C. R. (2008). Belajar dan pembelajaran prasekolah dan sekolah dasar. Jakarta: Indeks.

Shin, M., \& Lee, S. Y. (2011). Exploring the Connection between a Developmental

Vol. 1 No. 2 |95-96

Copyright @ 2020 | JECE | P-ISSN 2686-2492 
Change and Relationship Development with Caregivers and Peers, 5(2), 1-26.

Sudono, A. (2000). Sumber Belajar dan Alat Permainan untuk Pendidikan Anak Usia Dini. Grasindo.

Susanto, A. (2016). Perkembangan Anak Usia Dini.

Taggart, M., Koskela, L., \& Rooke, J. (2014). The Role of the Supply Chain in the Elimination and Reduction of Construction Rework and Defects: An Action Research Approach. Construction Management and Economics, 32(7-8), 829-842.

Tarwiyah, T. (2010). Pelestarian Budaya Betawi Permainan Anak Cici Putri dan

Ulabang/Wak Wak Gung: Kajian Kandungan Kecerdasan Jamak. Harmonia: Journal of Arts Research and Education, 10(1).

Tedjasaputra, M. S. (2001). Bermain, Mainan dan Permainan. Grasindo.

Yudrik, J. (2011). Psikologi Perkembangan. Jakarta. Kencana. 